\title{
Detrimental physiological effects of the invasive alga Caulerpa racemosa on the Mediterranean white seabream Diplodus sargus
}

\author{
Antonio Terlizzi ${ }^{1, *}$, Serena Felline ${ }^{1}$, Maria Giulia Lionetto ${ }^{1}$, Roberto Caricato ${ }^{1}$, \\ Vincenzo Perfetti ${ }^{2}$, Adele Cutignano ${ }^{2}$, Ernesto Mollo ${ }^{2}$
}

${ }^{1}$ Dipartimento di Scienze e Tecnologie Biologiche ed Ambientali, Università del Salento, CoNISMa, 73100 Lecce, Italy

${ }^{2}$ Istituto di Chimica Biomolecolare, CNR, Via Campi Flegrei 34, 80078 Pozzuoli, Naples, Italy

\begin{abstract}
Observational data suggest that the white seabream Diplodus sargus, a sparid fish of economic and ecological relevance in the Mediterranean Sea, has included the invasive green alga Caulerpa racemosa in its diet. Here we adopted a chemoecological approach to study the trophic relationship between the fish and the exotic pest. We demonstrated that the red pigment caulerpin, the most abundant secondary metabolite of C. racemosa, enters food chains and accumulates in the fish tissues. General biological condition markers associated with fish health and reproductive development were measured and correlated with the caulerpin levels in the fish tissues. Significant correlations among caulerpin tissue load (determined by liquid chromatography-mass spectrometry analysis) and fish condition factor and hepatosomatic index were obtained, suggesting a possible detrimental effect of the dietary exposure to C. racemosa on D. sargus. Glutathione peroxidase and catalase activity were also significantly correlated with caulerpin concentrations in the liver, suggesting a possible interaction between algal metabolites and liver antioxidant mechanisms. Studies on the impact of invasive macroalgae on marine assemblages have been almost exclusively focused on the structural modification of benthic assemblages, through the alteration of the relative importance of some endemic species and the modification of habitat complexity. Here we propose a new mechanism by which invasive algae can impact marine systems, namely the entry of pest metabolites in food webs, with potential detrimental effects on the population dynamics of a single species, alteration of trophic webs and changes in the functioning of coastal ecosystems.
\end{abstract}

KEY WORDS: Caulerpa racemosa $\cdot$ Diplodus sargus $\cdot$ Pest metabolites $\cdot$ Food webs $\cdot$ Biomarkers · Mediterranean Sea

\section{INTRODUCTION}

Approximately 100 alien macrophytes have been recorded in the Mediterranean basin (Ribera Siguan 2002, Gravili et al. 2010). Among these, Caulerpa racemosa (Forsskål) J. Agardh var. cylindracea (Sonder) Verlaque, Huisman and Boudouresque (Verlaque et al. 2003) has been reported to invade soft seagrasses and rocky habitats to depths ranging from 0 to $70 \mathrm{~m}$, with the potential to alter the structure and the composition of invaded assemblages (Balata et al. 2004, Box et al. 2010). In Italy, C. racemosa was reported for the first time in 1993 (Piazzi et al. 1997). In the Mediterranean
Sea, the Italian coasts are the most affected by $C$. racemosa's invasion (Piazzi et al. 2005).

Caulerpa racemosa is eaten by many invertebrates, such as the gastropods Ascobulla fragilis, Lobiger serradifalci and Bittium reticulatum, the echinoid Sphaerechinus granularis and the sparid fish Boops boops, Sarpa salpa, Pagellus acarne and Spondyliosoma cantharus (Klein \& Verlaque 2008, Box et al. 2009 and references therein). Caulerpales produce secondary metabolites that have been previously investigated for their ecological role both in the chemical defence against herbivores (McConnell et al. 1982, Pesando et al. 1996, Lemée et al. 1997) and as allelochemicals in in- 
terspecific competition among marine macrophytes (Raniello et al. 2007). Various studies have evaluated the toxic effect of these compounds on vertebrates and invertebrates (Lemée et al. 1993, Schröder et al. 1998, Barbier et al. 2001, Mozzachiodi et al. 2001, Paul et al. 2007). The homogenate of Caulerpa taxifolia affects the physiology of the black scopionfish Scorpaena porcus by altering enzymatic detoxification systems in their livers (Uchimura et al. 1999). More recently, it was revealed that the toxicity of Caulerpales in fish may be related to an increased production of reactive oxygen species (ROS), leading to oxidative damage. The activation of the antioxidant defence systems was evidenced in fish living in Caulerpa mats, namely the labrid Coris julis (Sureda et al. 2006) and the sparid Spondyliosoma cantharus (Box et al. 2009).

Toxic effects have also been reported in humans exposed to these metabolites after ingestion of the sparid fish Sarpa salpa, naturally feeding on Caulerpa spp. (De Haro et al. 1993). These findings lead to the hypothesis that there are harmful effects on nonadapted fish populations, such as those typical of the invaded systems, whose lack of an evolutionary heritage makes them unable to face metabolites which are new to their systems. The white seabream Diplodus sargus is a widespread Mediterranean sparid fish species inhabiting shallow rocky and seagrass beds (Sala \& Ballesteros 1997). D. sargus is mainly targeted by the artisanal and recreational fishery and constitutes a valuable fishery resource. Its diet is mainly composed of benthic invertebrates, namely bivalves, sea-urchins, barnacles and, to a lesser extent, decapods, polychaetes, crustacean peracarids and different algal species (Sala \& Ballesteros 1997).

Diplodus sargus is among the main predators of sea urchins (Sala \& Zabala 1996), which are the most important grazers in the Mediterranean rocky subtidal. Overdrive grazing by sea urchins can modify the structure of the habitat and diminish benthic diversity by shifting complex algal communities to barren areas (Shears \& Babcock 2002). In the Mediterranean Sea, the white seabream seems to play a key role in preventing the demographic explosion of sea urchin populations, with positive cascade effects on algal communities (Guidetti 2006). Observational, unpublished data suggest that, as a likely consequence of the heavy dominance of the invasive alga in the seabed, D. sargus has included Caulerpa racemosa in its diet.

Contrasting data have been reported on the distribution of Caulerpa racemosa metabolites in different parts of the alga, but it seems clear that caulerpin is the most abundant compound. Caulerpin is a red bisindolic pigment that is present in C. racemosa and absent in the congeneric Mediterranean C. prolifera (Schwede et al. 1986).
The present study: (1) evaluates the importance of Caulerpa racemosa in the Diplodus sargus diet, (2) assesses whether, and to what extent, the presence of an invasive species in the diet of an endemic fish species can affect accumulation of the algal secondary metabolites in the fish tissues and (3) investigates the potential effects of the C. racemono-based diet on the general health status of D. sargus.

Even though recent publications have highlighted the importance of a chemoecological approach in the evaluation of marine biological invasions (Raniello et al. 2007, Mollo et al. 2008), to our knowledge, the present paper represents the first attempt focusing on a possible accumulation of metabolites from invasive pests in Mediterranean fish.

\section{MATERIALS AND METHODS}

Fish sampling. Diplodus sargus individuals were obtained in the late summer of 2008, when Caulerpa racemosa flourish. They were provided by contestants in a national spearfishing competition along the south Salento coast (south of Apulia, SE Italy, Mediterranean Sea). Biomonitoring surveys conducted in recent years (Lionetto et al. 2001, 2003) characterised this area as relatively pristine from evident sources of chemical pollution.

The Italian spearfishing competition rules fix a minimum size for tournament fish at $400 \mathrm{~g}$ ind. ${ }^{-1}$, i.e. species $>400 \mathrm{~g}$ are weighed for the compilation of the score sheet. In order to reduce the interval between spearing (i.e. point of capture) and processing of the fish and to avoid issues of proteolysis in the liver postcapture, we restricted our sample to a single size class, i.e. fish generally not considered valid for the purpose of competition scoring. Spearfishers were equipped with dry ice. Once speared, each fish was immediately frozen and stored at about $-80^{\circ} \mathrm{C}$ until transportation to the laboratory, where they were immediately processed. Overall, a total of 20 specimens, with a mean weight of $305 \mathrm{~g}(\mathrm{SE}=17)$ and a mean length of $21.3 \mathrm{~cm}$ ( $\mathrm{SE}=0.8)$, were considered in the analyses. Limiting the analyses to a single size class also avoided a potential source of error due to changes in the accumulation of caulerpin in relation to fish size.

In the laboratory, the liver was rapidly excised from each sample and weighed. One gram of liver was frozen in liquid nitrogen and maintained at $-80^{\circ} \mathrm{C}$, whereas the remaining portion was stored at $-20^{\circ} \mathrm{C}$ until it was processed for biochemical and chemical analyses.

Stomachs were removed by severing the oesophagus near the buccal cavity and intestine, just anterior to the pyloric caecae, weighed and preserved in $70 \%$ ethanol. Each fish specimen was then dissected into 3 
sections: skin, white and red muscle, each of them was weighed and stored at $-20^{\circ} \mathrm{C}$ until chemical analysis.

At the same time, Caulerpa racemosa samples were also collected along the coasts of Apulia and stored at $-20^{\circ} \mathrm{C}$ until analysed.

Condition biomarkers. On each individual the following measurements were recorded: total length $(L)$ and total weight $(W)$, eviscerated weight $\left(W_{\mathrm{e}}\right)$, gonad wet weight $\left(W_{\mathrm{g}}\right)$ and liver wet weight $\left(W_{1}\right)$. All weights were obtained with electronic balances with a precision of $0.01 \mathrm{mg}$. Lengths were measured to the nearest $0.1 \mathrm{~mm}$ using a calliper.

Three main types of general biological condition markers associated with fish health and reproductive development were calculated individually for each of the 20 sampled specimens: fish condition (condition factor, CF), relative gonad size (gonadosomatic index, GSI) and relative liver size (hepatosomatic index, HSI). $\mathrm{CF}=100\left(W_{\mathrm{e}}-W_{\mathrm{g}}\right) / L^{3}$ serves as an indicator of growth, nutritional state and the energy content of the fish (Janssen et al. 1995). GSI $=100 W_{\mathrm{g}} /\left(W_{\mathrm{e}}-W_{\mathrm{g}}\right)$ serves as an indicator of the gonadal state of the animal. HSI = $100 W_{\mathrm{l}} /\left(W_{\mathrm{e}}-W_{\mathrm{g}}\right)$ is an indicator of the energy reserves of the organisms and is heavily affected when the organisms are exposed to chemical or physical stress conditions.

Oxidative stress biomarkers. Oxidative stress has recently been related to the health of wild fish populations (Di Giulio \& Meyer 2008), and the occurrence of oxidative stress has been proposed in the biotransformation of Caulerpales metabolites by fish species and in their adaptation to the presence of these algae (Sureda et al. 2006). Therefore, the antioxidant enzyme response in the liver of Diplodus sargus was also analysed. Catalase (CAT) and glutathione peroxidase (GSH-Px) activities were selected as oxidative stress biomarkers (Livingstone 2001).

Enzymatic activities such as CAT and GSH-Px activity were measured in each liver sample of the 20 specimens collected. CAT activity was assayed by the method of Clairborne (1985) on sample homogenates obtained by homogenizing the soft tissue in a 1:5 (tissue weight:buffer volume) ratio in ice-cold phosphate buffer $(50 \mathrm{mM}, \mathrm{pH} 7)$. Briefly, the assay mixture consisted of phosphate buffer $\left(\mathrm{KH}_{2} \mathrm{PO}_{4} 50 \mathrm{mM}, \mathrm{pH} 7\right)$ and hydrogen peroxide $(0.036 \%)$ in a final volume of $3 \mathrm{ml}$. CAT activity was calculated as the micromoles of $\mathrm{H}_{2} \mathrm{O}_{2}$ consumed per minute per milligram of proteins.

GSH-Px activity was assayed by the method of Wendel (1980) on sample homogenates, obtained by homogenizing the tissue in a 1:5 (tissue weight:buffer volume) ratio in $10 \mathrm{mM}$ ice-cold sodium phosphate buffer containing $1 \mathrm{mM}$ dithiothreitol (DTT) ( $\mathrm{pH}$ 7). The assay mixture consisted of phosphate buffer $\left(\mathrm{NaH}_{2} \mathrm{PO}_{4} 50 \mathrm{mM}\right.$, EDTA $0.4 \mathrm{mM}$, pH 7), 1 mM sodium azide, $1 \mathrm{IU} \mathrm{ml}^{-1}$ glutathione reductase, $1 \mathrm{mM} \mathrm{GSH}$, $0.2 \mathrm{mM}$ NADPH and $0.25 \mathrm{mM} \mathrm{H}_{2} \mathrm{O}_{2}$ in a total volume of $2 \mathrm{ml}$. Oxidation of NADPH was recorded spectrophotometrically at $340 \mathrm{~nm}$. The enzyme activity was calculated as the nanomoles of NADPH oxidized per minute per milligram of proteins. Protein concentration was measured using the Bio-Rad Protein Assay Kit 1 based on the Bradford dye-binding procedure (Bradford 1976), using lyophilized bovine plasma gamma globulin as a standard.

All biomarkers for general condition and oxidative stress were analysed in correlation with Caulerpa racemosa metabolite levels in fish tissues.

Gut content analysis. Stomach contents were observed under magnification and identified to the lowest possible taxonomic level, depending on the type and digestion level of each prey item. The wet weight of each item was recorded after superficial drying with absorbing paper. Frequency of occurrence $(O, \%)-$ the percentage of non-empty stomachs that contained a particular prey item:

$$
O=\frac{\mathrm{n}_{i}}{\sum_{i=1}^{i=n} \mathrm{n}_{i}} \times 100
$$

and percentages by weight of prey $(W, \%)$ - the ratio of the weight of a prey category $\left(W_{i}\right)$ to the total weight of the stomach content $\left(W_{\mathrm{T}}\right)$ :

$$
W=\left(\frac{W_{i}}{W_{T}}\right) \times 100
$$

were calculated. These indices were then combined to calculate the modified index (MI) of relative importance (Hayse 1990):

$$
\mathrm{MI}=\left(\frac{(W \times O)}{\sum(W \times O)}\right) \times 100
$$

Acquisition of standard compounds. Caulerpa racemosa (500 g fresh weight) was exhaustively extracted by acetone at room temperature both by ultrasound vibration and grinding in a blender ( 3 times). The acetone extract was evaporated at reduced pressure, and the residual water was extracted with diethyl ether. The diethyl ether extract $(0.65 \mathrm{~g})$ was subjected to chromatographic purifications following the method proposed by Raniello et al. (2007), to give $2.0 \mathrm{mg}$ of pure caulerpenyne, $25.2 \mathrm{mg}$ of pure caulerpin and $5.1 \mathrm{mg}$ of caulerpicin mixture.

The compounds were identified by comparison of ${ }^{1} \mathrm{H}$ - and ${ }^{13} \mathrm{C}-\mathrm{NMR}$ (proton and carbon nuclear magnetic resonance)-recorded data with the literature values (Amico et al. 1978, Maiti et al. 1978, Nielsen et al. 1982). NMR spectra were recorded on Bruker AM $400 \mathrm{MHz}$ and Bruker DPX $300 \mathrm{MHz}$ spectrometers in $\mathrm{CDCl}_{3}$ and DMSO-d6. Silica gel chromatography was carried out using precoated Merck F254 plates and 
Merck Kieselgel 60 powder. Thin-layer chromatography (TLC) spots were visualized by spraying with ceric sulphate and heating.

Extraction of animal sections and liquid chromatography-mass spectrometry (LC-MS) quantification of caulerpin in fish tissues. Samples of fish tissues were separately and exhaustively extracted with acetone by both ultrasound and homogenizing with a pestle. The extracts were filtered on paper, and the clear filtrates were evaporated under vacuum. After removing the organic solvent, the aqueous residues were further extracted 3 times with ethyl acetate.

Organic extracts were dried under nitrogen and reconstituted in $\mathrm{MeOH}$ at a final concentration of $0.5 \mathrm{mg}$ $\mathrm{ml}^{-1}$. Reverse phase high-performance liquid chromatography mass spectrometry (RP-HPLC-MS) analyses were carried out on a C-18 Gemini column (Phenomenex, $150 \times 2.0 \mathrm{~mm}, 5 \mu \mathrm{m})$ at room temperature. The injection volume was $20 \mu \mathrm{l}$. The mobile phase consisted of a MeOH: $\mathrm{H}_{2} \mathrm{O}$ gradient from 70:30 to 90:10 in $15 \mathrm{~min}$ (flow $0.2 \mathrm{ml}$ ), monitoring peak elution with a photodiode array (PDA) detector, coupled with a Q-Tof micro mass spectrometer (Waters) in electrospray ionization (ESI)-positive ion mode. The caulerpin calibration curve was prepared in methanol by adding known amounts of caulerpin. It consisted of 2 blank samples and 5 calibration points (in triplicate) at concentrations ranging from 10 to $10000 \mathrm{ng} \mathrm{ml}^{-1}$. The resulting peak areas were plotted against the concentrations.

\section{RESULTS}

\section{Diet analysis}

Caulerpa racemosa represented the most important prey type (according to the MI in \%), followed by Mollusca, Echinodermata and Crustacea (Table 1). C. racemosa was also the most frequently found item in the stomach of Diplodus sargus $(O=81.25 \%)$ followed by Mollusca, Crustacea and other algal species. Bryozoa and Tunicata were also well represented (Table 1).

\section{LC-MS quantifications of caulerpin in Diplodus sargus tissues}

The only algal metabolite detected in Diplodus sargus tissues by qualitative HPLC was caulerpin, which also turned out to be the main component in the Caulerpa racemosa lipophilic extract. Caulerpin concentrations, expressed per gram of wet weight $\left(\mu \mathrm{g} \mathrm{g}^{-1}\right)$, ranged from 0 to $7.50 \mu \mathrm{g} \mathrm{g}^{-1}$ in white muscle, 0 to 56.09 $\mu \mathrm{g} \mathrm{g}^{-1}$ in red muscle, 0 to $22.55 \mu \mathrm{g} \mathrm{g}^{-1}$ in the skin and 0 to $25.69 \mathrm{\mu g} \mathrm{g}^{-1}$ in the liver. The values of caulerpin bio-
Table 1. Diplodus sargus. Diet composition of white seabream in terms of frequency of occurrence $(O)$, percentage by weight $(W)$ and modified index of relative importance (MI)

\begin{tabular}{|llrr|}
\hline Food items & $O(\%)$ & $W(\%)$ & MI $(\%)$ \\
\hline Caulerpa racemosa & 81.25 & 32.55 & 45.25 \\
Other algae & 68.75 & 1.97 & 2.31 \\
Serpulidae & 31.25 & 1.87 & 1.00 \\
Other Polychaeta & 25 & 2.29 & 0.98 \\
Mollusca & 75 & 12.64 & 16.23 \\
Bryozoa & 50 & 8.11 & 6.93 \\
Echinodermata & 31.25 & 21.10 & 11.28 \\
Tunicata & 37.5 & 2.49 & 1.60 \\
Porifera & 25 & 2.72 & 1.16 \\
Crustacea & 62.5 & 11.16 & 11.93 \\
Rock fragments & 25 & 3.11 & 1.33 \\
\hline
\end{tabular}

accumulation in the different tissues of each sampled fish are reported in Table 2 . Considering the percentage distribution of caulerpin in all the tissues analyzed, about $44 \%$ was found in red muscle, $31 \%$ in the liver, $21 \%$ in the skin and only a small percentage in white muscle, which is usually the part of the fish consumed.

\section{General condition markers}

The values of general condition markers ranged

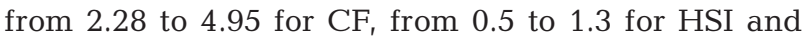
from 0.01 to 0.76 for GSH. Significant correlations were found between condition markers and the levels of caulerpin in tissues (Table 3). In particular, CF showed a significant negative correlation with caulerpin accumulation in all tissues analysed (Table 3), suggesting a

Table 2. Diplodus sargus. Values of caulerpin bioaccumulation $\left(\mu \mathrm{g} \mathrm{g}^{-1}\right)$ in the different tissues of fish sampled

\begin{tabular}{|lrrrr|}
\hline Fish & Liver & Red muscle & White muscle & Skin \\
\hline 1 & 0.00 & 0.00 & 0.00 & 0.00 \\
2 & 0.00 & 0.00 & 0.00 & 0.00 \\
3 & 2.72 & 1.73 & 0.48 & 0.89 \\
4 & 0.00 & 0.00 & 0.00 & 0.00 \\
5 & 0.00 & 0.00 & 0.00 & 0.00 \\
6 & 0.00 & 0.00 & 0.00 & 0.00 \\
7 & 1.00 & 1.77 & 0.17 & 1.00 \\
8 & 0.85 & 3.37 & 0.03 & 1.96 \\
9 & 0.40 & 2.54 & 0.23 & 2.35 \\
10 & 0.70 & 3.09 & 0.30 & 2.47 \\
11 & 8.53 & 17.42 & 1.65 & 5.08 \\
12 & 3.73 & 42.84 & 0.18 & 2.53 \\
13 & 2.55 & 4.84 & 0.17 & 3.87 \\
14 & 3.10 & 3.99 & 1.02 & 22.55 \\
15 & 14.01 & 5.74 & 0.00 & 0.00 \\
16 & 9.98 & 33.60 & 2.32 & 10.46 \\
17 & 1.87 & 4.51 & 0.24 & 3.84 \\
18 & 16.74 & 23.25 & 1.67 & 4.34 \\
19 & 25.69 & 56.09 & 7.50 & 14.21 \\
20 & 11.92 & 23.62 & 2.36 & 6.45 \\
& & & & \\
\hline
\end{tabular}


Table 3. Diplodus sargus. Regression parameters from linear correlations between condition markers (dependent) and caulerpin levels (independent). CF: condition factor; HSI: hepatosomatic index; $r$ : correlation coefficient; $\mathrm{p}$ : significance level of the correlation; $\mathrm{m}$ : slope of the correlation line; ns: not significant

\begin{tabular}{|c|c|c|c|c|c|c|}
\hline & \multicolumn{3}{|c|}{$\mathrm{CF}$} & \multicolumn{3}{|c|}{$\mathrm{HSI}$} \\
\hline & $\mathrm{r}$ & $\mathrm{p}$ & $\mathrm{m}$ & $\mathrm{r}$ & $\mathrm{p}$ & $\mathrm{m}$ \\
\hline Liver & 0.62 & $<0.001$ & -0.09 & 0.76 & $<0.001$ & 0.02 \\
\hline White muscle & 0.5 & 0.005 & -0.29 & 0.57 & $<0.001$ & 0.06 \\
\hline Red muscle & 0.66 & $<0.001$ & -0.04 & 0.69 & $<0.001$ & 0.01 \\
\hline Skin & 0.62 & $<0.001$ & 0.11 & 0.22 & ns & 0.01 \\
\hline
\end{tabular}

possible effect of the Caulerpa racemosa-based diet on fish growth and nutritional status.

HSI was positively correlated with caulerpin tissue levels for liver and red and white muscles (Table 3), suggesting that the consumption of Caulerpa racemosa can induce liver hypertrophy in the animal. No significant correlation was found between caulerpin content and GSI.

\section{Oxidative stress biomarkers}

The levels of enzymatic activities measured ranged from 11 to $80 \mathrm{mU} \mathrm{mg}^{-1}(32.75 \pm 2.9 \mathrm{SE}, \mathrm{n}=20)$ for GSH-Px and from 192 to $483 \mathrm{U} \mathrm{mg}^{-1}(338.78 \pm 16.45)$ for CAT.
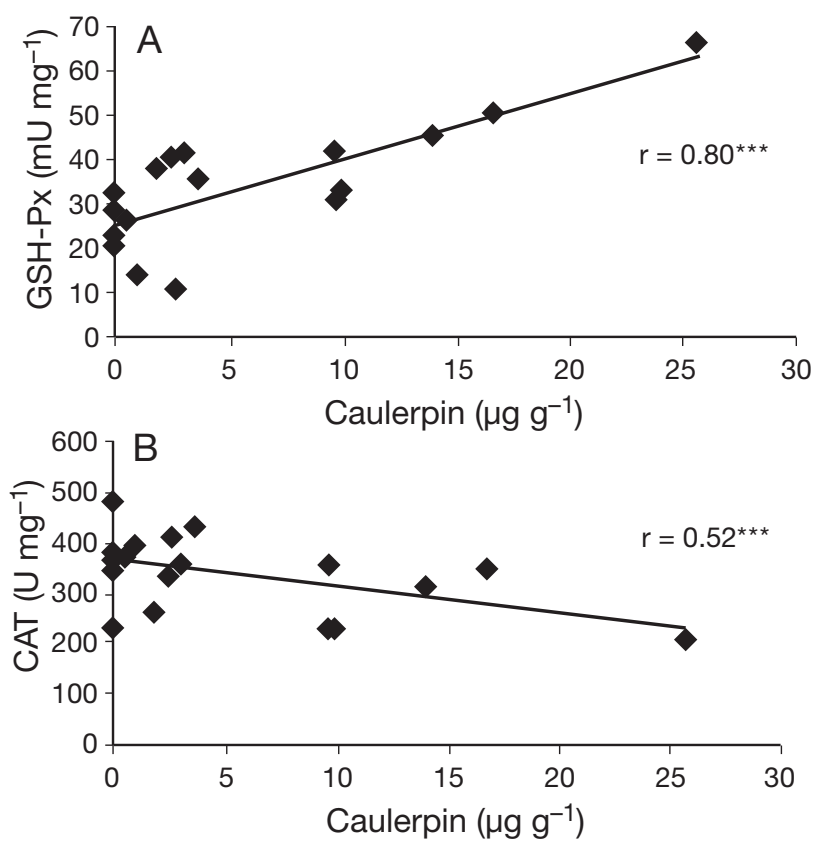

Fig. 1. Diplodus sargus. Correlations between caulerpin levels in fish liver and (A) GSH-Px and (B) CAT activity. Each unit (U) is expressed as $\mu \mathrm{mol}$ of $\mathrm{H}_{2} \mathrm{O}_{2}$ consumed $\mathrm{min}^{-1} \mathrm{mg}^{-1}$ protein. ${ }^{* * *}$ Significance level $(<0.001)$ of the correlation
When the antioxidant activities were related to caulerpin concentration in the liver, significant correlations were found (Fig. 1). Hepatic GSH-Px activity was positively correlated with caulerpin levels in the liver (Fig. 1A), suggesting a possibly increased antioxidant response in relation to Caulerpa racemosa exposure. Hepatic catalase activity was negatively correlated with caulerpin concentration in liver (Fig. 1B).

\section{DISCUSSION}

Biological invasions are acknowledged to be among the most severe threats to terrestrial and marine biodiversity. Although studies have assessed structural changes caused by the introduction of non-indigenous species on native assemblages (Vázquez-Luis et al. 2008, Baldacconi \& Corriero 2009, Demopoulos \& Smith 2010), less attention has been paid to understanding the complex indirect effects of invasive pest metabolites on marine biodiversity at the species and ecosystem levels.

In the present study we showed that Diplodus sargus feeds on Caulerpa racemosa. Since its introduction in the Mediterranean, this is the first description of $C$. racemosa as a food item of white seabream. This novel trophic relationship has also been confirmed in this work on a chemical basis by determining that the red pigment caulerpin is accumulated in the fish tissues. The frequency of occurrence of the invasive algae in fish stomach contents suggests that $C$. racemosa has become an important component of its diet. These values are higher than those relating the general frequency of occurrence of algae reported in other studies (Sala \& Ballesteros 1997, Mariani 2001, Figueiredo et al. 2005, Leitão et al. 2007).

Box et al. (2009) suggested that the ingestion of Caulerpa racemosa by the sparid fish Spondyliosoma cantharus is somewhat unintentional, the algae being ingested while the fish is preying on the invertebrates living under the C. racemosa canopy. Using stable isotopes, Box et al. (2009) found that fish assimilate only negligible amounts of $C$. racemosa. Results from the feeding studies showed that the crude extract and isolated metabolites, caulerpenyne and caulerpin, did not act to deter feeding by herbivorous fishes, even at the highest natural concentrations, rather they are feeding attractants (Meyer \& Paul 1992). Further studies are thus necessary to evaluate whether algae are actively selected or accidentally ingested while feeding on invertebrate species.

The present study also confirms that caulerpin represents the main lipophilic metabolite of Caulerpa racemosa var. cylindracea (Raniello et al. 2007), while our previous investigations, in accordance with earlier 
findings by Schwede et al. (1986), failed to detect the red pigment in the congeneric Mediterranean endemic species C. prolifera (authors' unpubl. data). Our data, therefore, clearly indicate the dietary accumulation of caulerpin in Diplodus sargus as a consequence of C. racemosa ingestion. Caulerpin showed a special propensity to accumulate in liver and red muscle, tissues with high metabolic activity, supporting the idea that lipid metabolism could be related to the accumulation of non-polar xenobiotics in fish. However, if the lipophilic nature of the red pigment facilitates its bioaccumulation, it is also reasonable to hypothesize that the release of caulerpin could cause physiological effects when the fatty tissues are used for energy, as proposed by Serrano et al. (2008) for the accumulation of pollutants in Sparus aurata. This delayed effect could expose the organisms to a further threat, particularly during critical moments of their life cycle, e.g. during reduced food availability, stress responses and reproduction.

The general health of a population can be indicative of its reproductive potential and the fitness of its offspring. CF relates the combined effects of weight gain and length growth to fish shape and is based on the assumption that heavier fish at a given length are in better condition (Suthers 1998, Grant \& Brown 1999). In addition, such an index is a longer term indicator of nutritional status and growth (Vasconcelos et al. 2009) and relatively insensitive to short-term environmental changes (Hoque et al. 1998). A decrease in CF is usually interpreted as a depletion of energy reserves stored as liver glycogen or body fat in response to stress factors (Schreck 1982, 1990, Barton \& Schreck 1987, Weber \& Bosworth 2005). Here, CF showed a significant negative correlation with caulerpin tissue burden in all tissues analysed (liver, white muscle, red muscle and skin). This result suggests a possible detrimental effect of the dietary exposure to Caulerpa racemosa on animal nutritional status. Although the underlying physiological mechanisms of this observed potential detrimental effect are presently unknown, lower food intake or malabsorption of food substances, resulting in a lower energy uptake can be hypothesized in specimens ingesting C. racemosa. In addition, an increased energetic cost to animals for the digestion and biotrasformation of metabolites that are new to their systems cannot be excluded.

HSI is sensitive to the nutritional status of animals and gives a useful indication of energy reserves. The index is strongly affected when the organisms are exposed to chemical or physical stress conditions. Increases in HSI values are a common reaction to the exposure to lipophilic xenobiotics (dioxins, PCBs, PAH) in fish (van der Weiden et al. 1989, Engwall et al. 1994). The liver plays a central role in the biotransformation of exogenous molecules, and the increased biotransformation requirement posed by the exposure to exogenous compounds may induce hepatocellular hypertrophy. Positive correlations between HSI and concentrations of lipophilic contaminants have been reported in a number of previous studies (Slooff et al. 1983, Fabacher \& Baumann 1985, Gallagher \& Di Giulio 1989, Everaarts et al. 1993, Pinkney et al. 2001). The positive correlation between HSI and caulerpin tissue levels found in the present study could imply that the ingestion of Caulerpa racemosa exposes the liver of animals to a high burden of new lipophilic metabolites, which, in turn, could induce liver hypertrophy.

GSI or relative size of the gonads gives a measure of the state of maturity in fish. All the sampled fish showed sexual maturation as assessed by visual analysis of the gonads according to Mann \& Buxton (1998) and Mouine et al. (2007). The non-significant correlation between GSI and caulerpin tissue content lead us to exclude, at present, any effect of the Caulerpa racemosa-based diet on gross gonadal morphology.

Analysis of oxidative stress biomarkers was carried out to further examine the potential effect of Caulerpa racemosa on the general health status of Diplodus sargus. Enhanced intracellular generation of ROS and oxidative stress conditions are among the most important pathways of toxicity mediated by several classes of chemicals and biologically active compounds (Di Giulio et al. 1995, Halliwell \& Gutteridge 1999, Regoli et al. 2002, Santos et al. 2004), and variations in antioxidant defences are sensitive biomarkers, revealing varied prooxidant pressure (Regoli \& Principato 1995). ROS can be generated as by-products of biotransformation reactions of toxins or xenobiotics, and oxidative stress has also been proposed to occur in the biotransformation of caulerpales metabolites by fish species, and in their adaptation to the presence of these algae (Sureda et al. 2006). A previous study (Sureda et al. 2006) demonstrated higher levels of glutathione peroxidases, glutathione reductase and glutathione S-transferases in the labrid Coris julis sampled in areas containing $C$. taxifolia or $C$. prolifera, compared to control areas, while catalase activity remained unchanged.

GPx and CAT are the most important enzymes detoxifying $\mathrm{H}_{2} \mathrm{O}_{2}$. GPx also participates in the detoxification of lipid hydroperoxides using glutathione (Winston \& Di Giulio 1991). In the present study hepatic GSH-Px activity was positively correlated with caulerpin concentrations in the liver, suggesting a possible interaction between caulerpin and liver antioxidant mechanisms. Caulerpin biotransformation could lead to the formation of reactive intermediates able to induce lipid peroxidation, which, in turn, could be responsible for the increasing activity of GPx at increasing caulerpin liver concentrations. 
On the other hand, hepatic catalase activity was negatively correlated with the caulerpin concentrations in the liver, suggesting an inhibitory effect of the metabolite on the catalytic activity of the enzyme. Regoli \& Principato (1995) indicated a decrease in catalase activity in Mediterranean mussels as a transitory response to chemical contaminants during acute stress, and this could also be the case for Diplodus sargus.

Given the descriptive nature of our data and the correlative approach adopted, it is still impossible to infer a great deal about the ecological consequences of the phenomenon of caulerpin accumulation in fish tissues. Further investigations are needed to clarify the in vivo effect of a Caulerpa racemosa-based diet on Diplodus sargus responses. The outcome of the present study, however, leads us to propose new hypotheses about the indirect mechanisms, by which invasive algae, through secondary metabolites, could affect population dynamics. Given the ecological role played by $D$. sargus in the temperate rocky subtidal, these hypotheses, if confirmed by manipulative experiments, could represent a starting point from which the complex mechanisms involved in the impact of invasive species on marine biodiversity and the overall functioning of ecosystems can be elucidated.

Acknowledgements. The present study forms part of S. Felline's PhD thesis and was carried out within the framework of projects funded by MIUR, Provincia di Brindisi and CoNISMa. It represents a contribution towards the aims of the MARBEF Network of Excellence, which is funded by the community's sixth Framework Programme (Contract No. GOCECT-2003-505446) and the CMCC (Centro Euro-Mediterraneo per i Cambiamenti Climatici). The Federazione Italiana Pesca Sportiva e Attività Subacquee (F.I.P.S.A.S.) kindly provided the samples for analyses. Thanks to Maurizio Zappa for recording mass spectra.

\section{LITERATURE CITED}

> Amico V, Oriente G, Piattelli M, Tringali C, Fattorusso E, Magno S, Mayol L (1978) Caulerpenyne, an unusual sequiterpenoid from the green alga Caulerpa prolifera. Tetrahedron Lett 19:3593-3596

Balata D, Piazzi L, Cinelli F (2004) A comparison among assemblages in areas invaded by Caulerpa taxifolia and $C$. racemosa on a subtidal Mediterranean rocky bottom. PSZN I: Mar Ecol 25:1-13

Baldacconi R, Corriero G (2009) Effects of the spread of the alga Caulerpa racemosa var. cylindracea on the sponge assemblage from coralligenous concretions of the Apulian coast (Ionian Sea, Italy). PSZN I: Mar Ecol 30:337-345

Barbier P, Guise S, Huitorel P, Amade P, Pesando D, Briand C, Peyrot V (2001) Caulerpenyne from Caulerpa taxifolia has an antiproliferative activity on tumor cell line SK-N-SH and modifies the microtubulo network. Life Sci 70:415-429

Barton BA, Schreck CB (1987) Metabolic cost of acute physical stress in juvenile steelhead. Trans Am Fish Soc 116: $257-263$
Box A, Deudero S, Sureda A, Blanco A and others (2009) Diet and physiological responses of Spondyliosoma cantharus (Linnaeus, 1758) to the Caulerpa racemosa var. cylindracea invasion. J Exp Mar Biol Ecol 380:11-19

Box A, Martin D, Deudero S (2010) Changes in seagrass polychaete assemblages after invasion by Caulerpa racemosa var. cylindracea (Chlorophyta: Caulerpales): community structure, trophic guilds and taxonomic distinctness. Sci Mar 74:317-329

Bradford MM (1976) A rapid and sensitive method for the quantification of microgram quantities of protein utilizing the principle of protein-dye binding. Anal Biochem 72: $248-254$

Clairborne A (1985) Catalase activity. In: Grenwald RA (ed) Handbook of methods of oxygen radical research. CRC Press, Boca Raton, FL, p 283-284

De Haro L, Treffor MJ, Jouglard J, Perringue C (1993) Trois cas d'intoxication de type ciguateresque après ingestion de Sparidae de Méditerranée. Ichthyophysiol Acta 16: 133-146

Demopoulos AWJ, Smith CR (2010) Invasive mangroves alter macrofaunal community structure and facilitate opportunistic exotics. Mar Ecol Prog Ser 404:51-67

Di Giulio RT, Meyer JM (2008) Reactive oxygen species and oxidative stress. In: Di Giulio RT, Hinton DE (eds) The toxicology of fishes. CRC Press, Boca Raton, FL, p 273-325

> Di Giulio RT, Behar JV, Carlson DB, Hasspieler BM, Watson DE (1995) Determinants of species susceptibility to oxidative stress: a comparison of channel catfish and brown bullhead. Mar Environ Res 39:175-179

> Engwall M, Brunström B, Brewer A, Norrgren L (1994) Cytochrome P450IA induction by a coplanar PCB, a PAH mixture, and PCB-contaminated sediment extracts following microinjection of rainbow trout sac-fry. Aquat Toxicol 30:311-324

- Everaarts JM, Shugart LR, Gustin MK, Hawkins WE, Walker WW (1993) Biological markers in fish: DNA integrity, haematological parameters and liver somatic index. Mar Environ Res 35:101-107

Fabacher DL, Baumann PC (1985) Enlarged livers and hepatic microsomal mixed-function oxidase components in tumor-bearing brown bullheads from a chemically contaminated river. Environ Toxicol Chem 4:703-710

Figueiredo M, Morato T, Barreiros JP, Afonso P, Santos RS (2005) Feeding ecology of the white seabream, Diplodus sargus, and the ballan wrasse, Labrus bergylta, in the Azores. Fish Res 75:107-119

Gallagher EP, Di Giulio RT (1989) Effects of complex waste mixtures on hepatic monooxygenase activities in brown bullheads (Ictalurus nebulosus). Environ Pollut 62: 113-128

> Grant SM, Brown JA (1999) Variation in condition of coastal Newfoundland 0-group Atlantic cod (Gadus morhua): field and laboratory studies using simple condition indices. Mar Biol 133:611-620

> Gravili C, Belmonte G, Cecere E, Denitto F and others (2010) Non-indigenous species (NIS) along the Apulian coasts, Italy. Chem Ecol 26(Suppl):121-142

Guidetti P (2006) Marine reserves re-establish lost predatory interactions and cause community changes in rocky reefs. Ecol Appl 16:963-976

Halliwell B, Gutteridge JMC (1999) Free radicals in biology and medicine. Oxford University Press, Oxford

Hayse JW (1990) Feeding habits, age, growth, and reproduction of Atlantic spadefish Chaetodipterus faber (Pisces: Ephippidae) in South Carolina. Fish Bull 88:67-83

Hoque MT, Yusoff FM, Law AT, Syed MA (1998) Effect of 
hydrogen sulphide on liver somatic index and Fulton's condition factor in Mystus nemurus. J Fish Biol 52:23-30

Janssen PAH, Lambert JGD, Goos HJT (1995) The annual ovarian cycle and the influence of pollution on vitellogenesis in the flounder, Pleuronectes flesus. J Fish Biol 47: 509-523

> Klein J, Verlaque M (2008) The Caulerpa racemosa invasion: a critical review. Mar Pollut Bull 56:205-225

> Leitão F, Santos MN, Monteiro CC (2007) Contribution of artificial reefs to the diet of the white sea bream (Diplodus sargus). ICES J Mar Sci 64:473-478

Lemée R, Pesando D, Durand-Clément M, Dubreuil A, Meisnez A, Guerriero A, Pietra F (1993) Preliminary survey of toxicity of the green alga Caulerpa taxifolia introduced into the Mediterranean. J Appl Phycol 5:485-493

- Lemée R, Pesando D, Issanchou C, Amade P (1997) Microalgae: a model to investigate the ecotoxicity of the green alga Caulerpa taxifolia from the Mediterranean Sea. Mar Environ Res 44:13-25

> Lionetto $\mathrm{MG}$, Giordano ME, Caricato $\mathrm{R}$, Pascariello MF, Marinosci L, Schettino T (2001) Biomonitoring of heavy metal contamination along the Salento coast (ITALY) by metallothionein evaluation in Mytilus galloprovincialis and Mullus barbatus. Aquat Conserv 11:305-310

Lionetto MG, Caricato $\mathrm{R}$, Giordano ME, Pascariello MF, Marinosci L, Schettino T (2003) Integrated use of biomarkers (acetylcholinesterase and antioxidant enzymes activities) in Mytilus galloprovincialis and Mullus barbatus in an Italian coastal marine area. Mar Pollut Bull 46:324-330

Livingstone DR (2001) Contaminant-stimulated reactive oxygen species production and oxidative damage in aquatic organisms. Mar Pollut Bull 42:656-666

Maiti BC, Thomson RH, Mahendran M (1978) The structure of caulerpin, a pigment from Caulerpa algae. J Chem Res 4: 126-127

Mann BQ, Buxton CD (1998) The reproductive biology of Diplodus sargus capensis and D. cervinus hottentotus (Sparidae) off the south-east cape coast, South Africa. Cybium 22:31-47

Mariani S (2001) Cleaning behaviour in Diplodus spp.: Chance or choice? A hint for future investigations. J Mar Biol Assoc UK 81:715-716

> McConnell OP, Hughes PA, Targett NM, Daley J (1982) Effects of secondary metabolites from marine algae on feeding by the sea urchin, Lytechninus variegatus. J Chem Ecol 8: $1437-1453$

Meyer KD, Paul VJ (1992) Intraplant variation in secondary metabolite concentration in three species of Caulerpa (Chlorophyta: Caulerpales) and its effects on herbivorous fishes. Mar Ecol Prog Ser 82:249-257

Mouine N, Francour P, Ktari M, Chakroun-Marzouk N (2007) The reproductive biology of Diplodus sargus sargus in the Gulf of Tunis (central Mediterranean). Sci Mar 71:461-469

Mollo E, Gavagnin M, Carbone M, Castelluccio F and others (2008) Factors promoting marine invasions: a chemoecological approach. Proc Natl Acad Sci USA 105:4582-4586

Mozzachiodi R, Scuri R, Roberto M, Brunelli M (2001) Caulerpenyne, a toxin from the seaweed Caulerpa taxifolia, depresses after hyperpolarization in invertebrate neurons. Neuroscience 107:519-526

Nielsen PG, Carlé JS, Christophersen C (1982) Final structure of caulerpicin, a toxin mixture from the green alga Caulerpa racemosa. Phytochemistry 21:1643-1645

Paul VJ, Arthur KE, Ritson-Williams R, Ross C, Sharp K (2007) Chemical defenses: from compounds to communities. Biol Bull 213:226-251

> Pesando D, Lemée R, Ferrua C, Amade P, Girard JP (1996) Effects of caulerpenyne, the major toxin from Caulerpa taxifolia on mechanisms related to sea urchin egg cleavage. Aquat Toxicol 35:139-155

Piazzi L, Acunto S, Magri M, Rindi F, Balestri E (1997) Osservazioni preliminari sull'espansione di Caulerpa racemosa (Forsskål) J. Agardh sulle Secche della Meloria (Livorno, Italia). Biol Mar Medit 4:426-428

Piazzi L, Meinesz A, Verlaque M, Akçali B and others (2005) Invasion of Caulerpa racemosa var. cylindracea (Caulerpales, Chlorophyta) in the Mediterranean Sea: an assessment of the spread. Cryptogam Algol 26:189-202

> Pinkney AE, Harshbarger JC, May EB, Melancon MJ (2001) Tumor prevalence and biomarkers of exposure in brown bullheads (Ameiurus nebulosus) from the tidal Potomac River, USA, Watershed. Environ Toxicol Chem 20: 1196-1205

Raniello R, Mollo E, Lorenti M, Gavagnin M, Buia MC (2007) Phytotoxic activity of caulerpenyne from the Mediterranean invasive variety of Caulerpa racemosa: a potential allelochemical. Biol Invasions 9:361-368

Regoli F, Principato G (1995) Glutathione, glutathionedependent and antioxidant enzymes in mussel, Mytilus galloprovincialis, exposed to metals under field and laboratory conditions: implications for the use of biochemical biomarkers. Aquat Toxicol 31:143-164

Regoli F, Gorbi S, Frenzilli G, Nigro M, Corsi I, Focardi S, Winston GW (2002) Oxidative stress in ecotoxicology: from the analysis of individual antioxidants to a more integrated approach. Mar Environ Res 54:419-423

Ribera Siguan MA (2002) Review of non-native marine plants in the Mediterranean Sea. In: Leppäkoski E, Gollasch S, Olenin S (eds) Invasive aquatic species in Europe. Distribution, impacts and management. Kluwer Academic Publishers, Dordrecht, p 291-310

Sala E, Ballesteros E (1997) Partitioning of space and food resources by three fish of the genus Diplodus (Sparidae) in a Mediterranean rocky infralittoral ecosystem. Mar Ecol Prog Ser 152:273-283

Sala E, Zabala M (1996) Fish predation and the structure of the sea urchin Paracentrotus lividus populations in the NW Mediterranean. Mar Ecol Prog Ser 140:71-81

Santos MA, Pacheco M, Ahmad I (2004) Anguilla anguilla L. antioxidants responses to in situ bleached kraft pulp mill effluent outlet exposure. Environ Int 30:301-308

Schreck CB (1982) Stress and rearing of salmonids. Aquaculture 28:241-249

Schreck CB (1990) Physiological, behavioral, and performance indicators of stress. Am Fish Soc Symp 8:29-37

Schröder HC, Badria FA, Ayyad SN, Batel R and others (1998) Inhibitory effects of extracts from the marine alga Caulerpa taxifolia and of toxin from Caulerpa racemosa on multixenobiotic resistance in the marine sponge Geodya cydonium. Environ Toxicol Pharmacol 5:119-126

Schwede JE, Cardellina JHII, Grode SH, James TRJR, Blackmann AJ (1986) Distribution of the pigment caulerpin in species of the green alga Caulerpa. Phytochemistry 26: $155-158$

Serrano R, Barreda M, Blanes MA (2008) Investigating the presence of organochlorine pesticides and polychlorinated biphenyls in wild and farmed gilthead sea bream (Sparus aurata) from the western Mediterranean Sea. Mar Pollut Bull 56:963-972

Shears NT, Babcock RC (2002) Marine reserves demonstrate top-down control of community structure on temperate reefs. Oecologia 132:131-142

> Slooff V, VanKreijl CF, Baars AJ (1983) Relative liver weights and xenobiotic-metabolizing enzymes of fish from polluted surface waters in the Netherlands. Aquat Toxicol 4: 1-14 
Sureda A, Box A, Enseñat M, Alou E, Tauler P, Deudero S, Pons A (2006) Enzymatic antioxidant response of a labrid fish (Coris julis) liver to environmental caulerpenyne. Comp Biochem Physiol C 144:191-196

Suthers IM (1998) Bigger? Fatter? Or is faster growth better? Considerations on condition in larval and juvenile coralreef fish. Aust J Ecol 23:265-273

Uchimura M, Sandeaux R, Larroque C (1999) The enzymatic detoxifying system of a native Mediterranean scorpio fish is affected by Caulerpa taxifolia in its environment. Environ Sci Technol 33:1671-1674

van der Weiden MEJ, Craane LHJ, Evers EHG, Kooke RMM, Olie K, Seinen W, vab den Berg M (1989) Bioavailability of PCDDs and PCDFs from bottom sediments and some associated biological effects in the carp (Cyprinus carpio). Chemosphere 19:1009-1016

> Vasconcelos RP, Reis-Santos P, Fonseca V, Ruano M, Tanner S, Costa MJ, Cabral HN (2009) Juvenile fish condition in estuarine nurseries along the Portuguese coast. Estuar Coast Shelf Sci 82:128-138

Editorial responsibility: Francesco Patti, Naples, Italy
Vázquez-Luis M, Sanchez-Jerez P, Bayle-Sempere JT (2008) Changes in amphipod (Crustacea) assemblages associated with shallow-water algal habitats invaded by Caulerpa racemosa var. cylindracea in the western Mediterranean Sea. Mar Environ Res 65:416-426

Verlaque M, Durand C, Huisman JM, Boudouresque CF, Le Parco Y (2003) On the identity and origin of the Mediterranean invasive Caulerpa racemosa (Caulerpales, Chlorophyta). Eur J Phycol 38:325-339

Weber TE, Bosworth BG (2005) Effects of 28 day exposure to cold temperature or feed restriction on growth, body composition, and expression of genes related to muscle growth and metabolism in channel catfish. Aquaculture 246: 483-492

Wendel A (1980) Glutathione peroxidise. In: Jakoby WB (ed) Enzymatic basis of detoxification. Academic Press, New York, NY, p 333-353

Winston GW, Di Giulio RT (1991) Prooxidant and antioxidant mechanisms in aquatic organisms. Aquat Toxicol 19: 137-161

Submitted: December 13, 2010; Accepted: February 20, 2011 Proofs received from author(s): April 4, 2011 